\title{
Análise da eficácia terapêutica em três modelos fonológicos de abordagem contrastiva****
}

\author{
Therapeutic efficacy analysis of three contrastive approach \\ phonological models
}

\author{
Karina Carlesso Pagliarin* \\ Helena Bolli Mota** \\ Márcia Keske-Soares**
}

*Fonoaudióloga. Mestre em Distúrbios
da Comunicação Humana pela
Universidade Federal de Santa Maria
(UFSM). Professora do Curso de
Fonoaudiologia da UFSM. Endereço
para correspondência: R. Coronel
Scherer, 09 - São Pedro do Sul - RS -
CEP 97400-000
(karinap_fono@ yahoo.com.br).
**Fonoaudióloga. Doutora em
Linguística Aplicada pela Pontifícia
Universidade Católica do Rio Grande
do Sul (PUC - RS). Professor
Associado do Curso de
Fonoaudiologia e do Programa de Pós-
Graduação em Distúrbios da
Comunicação Humana da UFSM.
Bolsista de Produtividade em Pesquisa
2 do CNPq.

***Trabalho Realizado no Centro de Estudos de Linguagem e Fala (CELF) da UFSM.

Artigo Original de Pesquisa

Artigo Submetido a Avaliação por Pares

Conflito de Interesse: não

Recebido em 16.03.2009

Revisado em 10.08.2009; 13.09 .2009$.

Aceito para Publicação em 02.10.2009.

\begin{abstract}
Background: phonological therapy in subjects with phonological disorders. Aim: to compare the efficacy of three contrastive approach models in three different severities of phonological disorder. Method: participants of the study were nine subjects with phonological disorders, with ages ranging between 4:2 and 6:6 years. All subjects were evaluated prior to and after phonological therapy. Three groups, with three subjects each, were determined for treatment. Each group presented one individual with severe, one with moderate-severe and one with mild-moderate phonological disorder. Each group was treated using a different therapy model - Minimal Opposition, Maximal Oppositions/Empty Set and Multiple Opposition. Results were analyzed according to the Friedman Test, considering $\mathrm{p}<0.05$; a descriptive analysis was also performed among the models. Results: there was no statistical difference among the models considering the severity of phonological disorder. The Minimal and Maximal Oppositions/Empty Set approaches favored a greater number of sound acquisitions in the phonetic inventory of subjects with severe and moderate-severe disorder. On the other hand, the Multiple Oppositions approach favored a better performance of sound acquisition in the phonological system and a decrease in the impaired distinctive features in severe and moderate-severe disorder. Conclusion: the models of therapy were effective in the treatment of different severities of phonological disorders observing the best performance in children with severe and moderate-severe disorder.
\end{abstract}

Key Words: Child; Speech; Speech Disorders; Speech Therapy.

\section{Resumo}

Tema: terapia fonológica em crianças com desvio fonológico. Objetivo: comparar a eficácia de três modelos de abordagem contrastiva em três diferentes gravidades do desvio fonológico. Método: a amostra constituiu-se de nove sujeitos com desvio fonológico, com idades entre 4:2 e 6:6. Todos foram avaliados, antes e após a terapia fonológica. Foram estabelecidos três grupos para o tratamento, sendo todos constituídos por três sujeitos, cada grupo tinha um representante com desvio severo, moderado-severo e médio-moderado. Cada grupo foi tratado por um modelo - Oposições Mínimas, Oposições Máximas/ Empty Set e Oposições Múltiplas. Posteriormente, realizou-se análise estatística dos dados, utilizando o Teste de Friedman, considerando-se p < 0,05 e análise descritiva entre os modelos. Resultados: não houve diferença estatisticamente significante entre os modelos considerando-se a gravidade do desvio fonológico. Os Modelos de Oposições Mínimas e Oposições Máximas/Empty Set favoreceram maior número de aquisição de sons no inventário fonético nos sujeitos com graus severos e moderado-severo, enquanto que o Modelo de Oposições Múltiplas favoreceu melhor desempenho na aquisição de sons no sistema fonológico e diminuição dos traços distintivos alterados nos desvio severos e moderado-severos. Conclusão: os modelos de terapia foram eficazes no tratamento das diferentes gravidades do desvio fonológico, observando-se melhor desempenho das crianças com desvio severo e moderado-severo.

Palavras-Chave: Criança; Fala; Distúrbios da Fala; Fonoterapia.

Referenciar este material como:

1 Pagliarin KC, Mota HB, Keske-Soares M. Therapeutic efficacy analysis of three contrastive approach phonological models (original title: Análise da eficácia $\sum 3$ terapêutica em três modelos fonológicos de abordagem contrastiva). Pró-Fono Revista de Atualização Científica. 2009 out-dez;21(4):297-302. 


\section{Introduction}

The therapeutic intervention in phonologically disordered children is emphasized in many studies 16 and many advances have been observed, especially in relation to the different treatment approaches proposed nowadays 2,4 . The therapy with a phonological basis has motivated this progress, since it made the treatment more effective, because it aims at generalization 7 .

There are many therapeutic models available for the speech therapist to choose and adapt to the treatment of phonologically disordered children. However, sometimes it is difficult to know exactly which program to use and how to implement it8.

Based on this, different models have been applied and compared in order to ascertain their efficacy and effectiveness 8-11, but there are just a few studies about it yet. In a recent research 11, the authors analyzed the efficacy of the treatment in three different therapy models (ABAB - Withdrawal and Multiple Probes, Maximal Oppositions and Modified Cycles), concerning the changes in the phonological system of 66 subjects with different degrees of severity of phonological disorder. The authors found that the three therapy models were effective for the treatment of different degrees of severity of phonological disorder.

The present study aimed at comparing the efficacy of three models of contrastive approach (Minimal Oppositions, Maximal Oppositions/Empty Set and Multiple Oppositions) in three different degrees of severity of the phonological disorder, based on the phonological changes that were obtained.

\section{Method}

The research was based on a project that was registered and approved by the Research Ethics Committee, under $n^{\circ} 108 / 05$. Before the data collection, the parents read and signed the Term of Free and Informed Consent. The group of subjects was composed by nine children aged between $4: 2$ and 6:6, which were five boys and four girls. The subjects were chosen for the research according to the following criteria: to be older than 4; to have normal hearing ability for speech; to have normal structures and oral motor skills; not to have undergone phonological therapy before; to be member of a monolingual family speaker of Brazilian Portuguese; not to present neurological problems concerning speech production; to have adequate intellectual capacities for the development of spoken language; to have adequate language comprehension for the mental age; to present expressive language capacities apparently well developed, in terms of range of vocabulary and length of utterances; to be diagnosed with phonological disorder; the children who underwent the Multiple Oppositions Model should have a phonological system compatible with the model 2, that is, the substitution of many sounds with one sound. The subjects should also present different degrees of severity of the disorder, according to the classification of the Percentage of Consonants Correct (PCC) 12.

In order to make the phonological disorder diagnosis, all the subjects underwent the following phonological evaluations: medical history, informal observation of comprehensive and expressive language; stomatognathic system; auditory description; phonological awareness; vocabulary; simplified auditory processing; and phonological evaluation. The subjects also underwent the additional neurological and audiological evaluations.

The results of the evaluations agreed with the patterns of normality established for each age group, except for the phonological evaluation.

In order to obtain the speech data, it was used the Phonological Evaluation of the Child (PEC) Instrument 13 and for the analysis of the data it was used contrastive analysis and distinctive features analysis.

After the contrastive analysis, the phonetic inventory and the phonological system of each subject were obtained. Each sound was considered as part of the phonetic inventory when it occurred twice or more times, regardless of the position in the word. In order to obtain the phonological system, a segment was considered to be acquired when there were from $80 \%$ to $100 \%$ of correct productions, partially acquired from $40 \%$ to $79 \%$, and not acquired $0 \%$ to $39 \% 14$.

As for the altered distinctive features, all the alterations of distinctive features produced in minimum occurrence of $10 \%$ of the possibilities 15 were considered.

As for the calculation of the degree of severity of the phonological disorder, only the substitutions and omissions were considered "mistakes", according to the Percentage of Consonants Correct - Revised (PCCR) 16. The degree of severity of the disorder was classified according to what was proposed by a study 12 , in the following way: mild disorder (86 to 100\%); mild-moderate disorder (66 to $85 \%$ ); moderate-severe disorder (51 to $65 \%)$; and severe disorder $(<50 \%)$.

Finally, three research groups were established, which were treated with different contrastive approaches, all of them composed by subjects with three different degrees of severity of the phonological disorder, that is, each group had one subject with severe disorder (SD), one with moderate-severe disorder (MSD) and one with 
moderate-mild disorder (MMD).

The therapeutic planning used for each subject focused on the following contrastive approaches: Maximal Oppositions/Empty Set 1, 17-18, in which two target-sounds that are absent in the child's phonological system and that differ from each other in three or more distinctive features are selected; Minimal Oppositions 18, in which two new sounds that differ from each other in only one or two distinctive features are selected; and Multiple Oppositions 2,19, in which many sounds that are substituted for an only phoneme by the child are selected.

The subjects that were selected to participate in the research underwent the phonological therapy in the session structure proposed by one study 4 . In the therapeutic sessions the auditory bombardment, the practice of production and the parents' orientation were applied. During the therapeutic process, periodic phonological evaluations (follow-up) were made, aiming at verifying the improvements of the treatment. The children's treatment consisted of two weekly sessions, which lasted 45 minutes each.

Thirty therapy sessions were made, and classified for all the models in the following way: five sessions and one follow-up. After finishing the 25 sessions, the PEC was applied again, together with the PCC-R calculation.
Chart 1 shows the target-sounds selected for the therapy of each subject according to the chosen therapeutic model, just like the number of sessions.

S6 underwent 20 therapy sessions using the Maximal Oppositions/Empty Set Model, as he acquired all the phonemes that were absent in his phonological system. On the other hand, S8 underwent 15 therapy sessions using the Multiple Oppositions Model, once he presented only one sound that was absent in his phonological system after the follow-up, which showed the impossibility of continuing with the model, and then, PEC was applied.

S4, S6, S7 and S9 were treated during all the sessions with the same group of target-sounds, whereas S1, S2 and S5 were treated with different target-sounds, as they acquired those sounds in the follow-up, that is, they presented $80 \%$ of correct productions.

The data analysis considered, in each therapy model, the differential between the initial and final evaluations of the number of sounds that were present in the phonetic inventory (present sounds - PS), the number of phonemes that were established in the phonological system (established phonemes - EP) and the number of altered distinctive features (ADF).

For these analyses, Friedman Test with significance level of 5\% (p 0,05) was used, through the Program STATISTICA 7.0. After that, the descriptive analysis of the data was made.

CHART 1. Distribution of the subjects according to the therapeutic model and the target-sounds selected for the therapy and number of sessions

\begin{tabular}{|c|c|c|c|c|c|c|}
\hline Subject & Model & Severity & IPA* & Target-sound & $\begin{array}{c}\mathbf{N} \\
\text { Sessions }\end{array}$ & FPA* \\
\hline S1 & \multirow{3}{*}{ MínO } & SD & $\begin{array}{l}/ \mathrm{b} /, / \mathrm{d} /, / \mathrm{k} /, / \mathrm{g} /, / \mathrm{v} /, / \mathrm{s} /, / \mathrm{z} /, / 3 /, / 1 /, / \mathrm{r} / \\
/ \mathrm{N}, / \mathrm{R} /,[\mathrm{d} 3]\end{array}$ & $\begin{array}{l}\mathrm{k} / \mathrm{x} / \mathrm{g} /-\mathrm{IO} \\
/ \mathrm{d} / \mathrm{x} / \mathrm{g} /-\mathrm{IO}\end{array}$ & $\begin{array}{l}10 \\
15 \\
\text { Total } 25\end{array}$ & $\begin{array}{l}/ \mathrm{b} /, / \mathrm{d} /, / \mathrm{k} /, / \mathrm{g} /, / \mathrm{v} /, / \mathrm{s} /, / \mathrm{z} /, / 3 / \\
/ \mathrm{l} /, / \mathrm{r} /, / \mathrm{N}, / \mathrm{R} /,[\mathrm{d} 3]\end{array}$ \\
\hline S2 & & MSD & $/ \mathrm{t} /, / \mathrm{d} /, / \mathrm{S} /, / 3 /, / 1 /, / \mathrm{N}, / \mathrm{r} /, / \mathrm{t} \int /,[\mathrm{d} 3]$ & $\begin{array}{l}/ \mathrm{S} / \mathrm{x} / \mathrm{s} /-\mathrm{MO} \\
/ \mathrm{K} / \mathrm{x} / \mathrm{r} /-\mathrm{MO} \\
/ \mathrm{t} / \mathrm{x} / \mathrm{d} /-\mathrm{IO}\end{array}$ & $\begin{array}{l}5 \\
10 \\
10 \\
\text { Total } 25\end{array}$ & $/ \mathbb{N}, / \mathrm{r} /$ \\
\hline S3 & & MMD & $/ \mathrm{l}, / \mathrm{K} /, / \mathrm{R} /, / \mathrm{r} /$ & $\begin{array}{l}/ \mathrm{R} / \mathrm{x} / \mathrm{l} /-\mathrm{IO} \\
/ \mathrm{r} / \mathrm{x} / \mathrm{N}-\mathrm{MO}\end{array}$ & $\begin{array}{l}10 \\
15 \\
\text { Total } 25\end{array}$ & $/ \mathrm{r} /$ \\
\hline S4 & \multirow{3}{*}{$\mathrm{MaxO} / E S$} & SD & $\begin{array}{l}\text { /b/, /d/, /g/, /v/, /s/, /z/, /3/, /s/, /l, /K/, } \\
/ \mathrm{R} /, / \mathrm{r} /,[\mathrm{d} 3]\end{array}$ & $/ \mathrm{r} / \mathrm{x} / \mathrm{z} /-\mathrm{MO}$ & 25 & $\begin{array}{l}\text { /b/, /d/, /g/, /z/, /3/, /N,/R/, /r/, } \\
{\left[\mathrm{d}_{3}\right]}\end{array}$ \\
\hline S5 & & MSD & $\begin{array}{l}/ \mathrm{b} /, / \mathrm{d} /, / \mathrm{k} /, / \mathrm{g} /, / \mathrm{v} /, / \mathrm{z} /, / 3 /, / 1 /, / \mathrm{r} / \\
/ N, / \mathrm{R} /,\left[\mathrm{d}_{3}\right]\end{array}$ & $\begin{array}{l}/ \mathrm{k} / \mathrm{x} / \mathrm{l} / \mathrm{-IO} \\
\mathrm{l} / \mathrm{x} / \lambda-\mathrm{MO}\end{array}$ & $\begin{array}{l}10 \\
15 \\
\text { Total } 25\end{array}$ & $\begin{array}{l}\text { /b/, /d/, /k/,/g/, /v/,/z/, /3/, /l/, } \\
/ \mathrm{N}, / \mathrm{R} /, / \mathrm{r} /,[\mathrm{d} 3]\end{array}$ \\
\hline S6 & & MMD & $/ \mathrm{s} /, / \mathrm{z} /, / \mathrm{r} /$ & $\mathrm{l} / \mathrm{x} / \mathrm{N}-\mathrm{MO}$ & Total 20 & ---- \\
\hline S7 & \multirow{3}{*}{ MúlO } & SD & $\begin{array}{l}/ \mathrm{b} /, / \mathrm{d} /, / \mathrm{k} /, / \mathrm{g} /, / \mathrm{f} /, / \mathrm{v} /, / \mathrm{s} /, / \mathrm{z} /, / \mathrm{s} /, / \mathrm{z} /, \\
/ \mathrm{m} /, / \mathrm{n} /, / \mathrm{s} /, / \mathrm{l} /, / \mathrm{r} /, / \mathrm{K} /, / \mathrm{R} /,[\mathrm{d} 3]\end{array}$ & $/ / \mathrm{x} / \mathrm{z} / \mathrm{x} / 3 / \mathrm{x} / \mathrm{s} / \mathrm{MO}$ & Total 25 & $/ \mathrm{k} /, / \mathrm{g} /, / \mathrm{J} /, / \mathrm{Z} /, / \mathrm{V}, / \mathrm{K} /, / \mathrm{R} /, / \mathrm{r} /$ \\
\hline S8 & & MSD & $\begin{array}{l}\text { /b/, /d/, /g/, /v/, /z/, /S/, /3/, //, /r/, /K/, } \\
{\left[\mathrm{d}_{3}\right]}\end{array}$ & $\begin{array}{l}\text { I/x/z/x/z/x/r/x/R/ } \\
\mathrm{MO}\end{array}$ & Total 15 & $/ \mathrm{r} /$ \\
\hline S9 & & MMD & /b/, /d/, /g/,/v/,/z/,/3/,/l/, /N,/r/, [dz] & $/ \mathrm{s} / \mathrm{x} / \mathrm{z} / \mathrm{x} / \mathrm{s} / \mathrm{x} / 3 / \mathrm{MO}$ & Total 25 & /b/, /g/, /v/, /z/, /3/, /l/, /N, /r/ \\
\hline
\end{tabular}

Subtitle: MinO: Minimal Opposition. MaxO/ES: Maximal Opposition/Empty Set. MulO: Multiple Opposition. IO: Initial Onset. MO: Medial Onset. IPA: Initial Phonological Assessments. FPA: Final Phonological Assessment. SD: Severe Disorder. MSD: Moderate-Severe Disorder. MMD: Mild-Moderate Disorder. *absent sounds and partially acquired sounds based on the general phonological system. 


\section{Results}

Table 1 presents the nine subjects of this research, considering the therapeutic models and the degree of severity of the phonological disorder, using the results of the differential between before and after treatment for the identification of the sounds that are present in the phonetic inventory, of the phonemes that were established in the phonological system and of the number of distinctive features that were established by the different treatment models. In this table, there are also the results of the statistical analysis, in order to verify if there was any statistically relevant difference among the models.

Based on the statistical analysis, it was possible to observe that there is no statistically relevant difference among the models. Taking the degree of severity into consideration, it is possible to say that all the models are effective for the treatment of phonological disorder, since most subjects presented improvements in the phonetic inventory, the phonological system and the distinctive features.

As for the phonetic inventory, it was possible to see that the subject with SD (S1) acquired the greatest number of sounds in the Minimal Oppositions Model; in the Maximal Oppositions/ Empty Set Model, this occurs both for the subject with MSD (S5) and for the subject with SD (S4); and, in the Multiple Oppositions Model, the subject with SD (S7) obtained a better performance in this variable. It can be observed that the subject with MMD (S6), who underwent the Maximal Oppositions/Empty Set Model, did not acquire any sound, since he presented a complete phonetic inventory in the initial evaluation. Finally, it can be emphasized that the greatest number of sound acquisitions in the phonetic inventory was by the subjects treated by the Minimal Oppositions Model (S1), with SD, and the Maximal Oppositions/ Empty Set Model (S4 and S5), with SD and MSD, respectively.

As for the phonological system, it is possible to observe that the subject with MSD (S2) treated by the Minimal Oppositions Model, the one with MMD (S6) treated by the Maximal Oppositions/ Empty Set Model, and the one with MSD (S8) treated by the Multiple Oppositions Model, obtained the greatest changes in their phonological systems. In addition, it was possible to see that the best performance in the acquisition of sounds in the phonological system was by the subjects treated with the Multiple Oppositions Model with degrees MSD and SD. Neither the subject with SD (S1), who underwent the Minimal Oppositions Model, nor the subject with MSD (S5), who underwent the Maximal Oppositions/Empty Set Model, acquired a phoneme, presenting the same number of sounds in the initial and final phonological system.

It is possible to observe that the number of distinctive features was expressive, mainly in the subjects with MSD (S2), SD (S4), and MSD (S8) who underwent the Minimal Oppositions Model, the Maximal Oppositions/Empty Set Model, and the Multiple Oppositions Model, respectively.

The best performance in the suppression of the altered distinctive features was by the subjects treated by the Multiple Oppositions Model with MSD and SD. Besides, it was possible to see that the MMD group was the one who presented the smallest changes as to the distinctive features.

TABLE 1. Differential of the number of sounds that were present in the phonetic inventory, the number of phonemes that was established in the general phonological system and the number of altered distinctive features

\begin{tabular}{|c|c|c|c|c|c|}
\hline \multirow[t]{2}{*}{ Model } & \multirow[t]{2}{*}{ Degree } & \multirow[t]{2}{*}{ Subject } & $\begin{array}{l}\text { Phonetic } \\
\text { Inventory }\end{array}$ & $\begin{array}{c}\text { Phonological } \\
\text { System }\end{array}$ & $\begin{array}{c}\text { Distinctive } \\
\text { features }\end{array}$ \\
\hline & & & $\begin{array}{c}\mathbf{N}^{\circ} \text { of } \\
\text { PS }\end{array}$ & $\mathbf{N}^{\circ}$ of EP & $\begin{array}{l}\mathbf{N}^{\circ} \text { of } \\
\text { ADF }\end{array}$ \\
\hline \multirow{4}{*}{ MínO } & SD & S1 & 8 & 0 & 0 \\
\hline & MSD & S2 & 2 & 5 & 9 \\
\hline & MMD & $\mathbf{S 3}$ & 4 & 3 & 3 \\
\hline & SD & S4 & 6 & 3 & 11 \\
\hline \multirow{3}{*}{ MaxO/ES } & MSD & S5 & 6 & 0 & 4 \\
\hline & MMD & S6 & 0 & 5 & 3 \\
\hline & SD & S7 & 4 & 8 & 16 \\
\hline \multirow[t]{2}{*}{ MúlO } & MSD & S8 & 3 & 9 & 19 \\
\hline & MMD & S9 & 2 & 2 & 1 \\
\hline
\end{tabular}

Subtitle: MinO: Minimal Opposition. MaxO/ES: Maximal Opposition/Empty Set. MulO: Multiple Opposition. SD: Severe Disorder. MSD: Moderate-Severe Disorder. MMD: Mild-Moderate Disorder. PS: Present Sounds. EP: Established Phonemes. ADF: Altered Distinctive Features 


\section{Discussion}

The results showed that the therapeutic models used were effective for the treatment of the subjects, as all of them presented improvements in the following aspects in analysis: phonological system, phonetic inventory and distinctive features, corroborating studies $18,20,3$, in which the authors found, for each model individually, that they offered advantages in the children's phonological performance.

The subjects with SD and MSD were the ones who acquired more sounds in their phonetic inventories. This is due to the fact that, the more severe the degree of the disorder, more sounds are absent in the phonetic inventory, which makes it possible to obtain more phonological acquisitions, as all the models aim at generalization 7. The Maximal Oppositions/Empty Set Model and the Minimal Oppositions Model caused greater changes in the phonetic inventory than the Multiple Oppositions Model, especially with SD and MSD. This result may have been influenced by the initial phonetic inventory, as the subjects treated by the Multiple Oppositions Model presented fewer absent sounds in relation to the other models.

The results show that the subjects with MSD and MMD acquired the greatest number of phonemes in their phonological systems. These results agree with studies 11,21 , in which the authors found that the greatest changes in the phonological system occur in the groups with MMD and MSD. The subjects treated by the Multiple Oppositions Model acquired more segments in their phonological system, and this is due to the fact that, in this model, the child faces many sounds simultaneously, considering the substituted phoneme 2 , and not only two new sounds 18 .

\section{References}

1. Gierut JA. Maximal opposition approach to phonological treatment. J. Speech Hear. Dis. 1989;54:9-19.

2. Williams AL. Multiple oppositions: theoretical foundations for an alternative contrastive intervention framework. Am J. Speech Lang. Path. 2000a Nov;9:282-8.

3. Pagan LO, Wertzner HF. Intervenção no distúrbio fonológico por meio de pares mínimos com oposição máxima. Pró-Fono R. Atual. Cient. 2002 Set-Dez;14(3):313-24.
The degrees MSD and SD showed greater suppression of altered distinctive features. These findings may be justified by the fact that, in these degrees of severity, the phonological disorder is represented by disordered systems and with a smaller number of contrasts 15 .

The Multiple Oppositions Model improved the subjects' performance as to the sound acquisition in the phonological system and the suppression of altered distinctive features, due to the fact that this model allows the contrast of a greater number of sounds and, consequently, a greater number of features 2 .

\section{Conclusion}

The three models of contrastive analysis are effective for the treatment of phonological disorder, taking the different degrees of severity into consideration. Besides, it was possible to see that the subjects with SD and MSD acquired a greater number of sounds in their phonetic inventories, and the Minimal Oppositions Model and the Maximal oppositions/Empty Set Model were the ones that most influenced this change. However, it does not happen in the phonological system, as the subjects with MSD, who underwent the Minimal Oppositions Model, and MMD, who underwent the Maximal Oppositions/Empty Set Model, seem to better organize the sound system. The Multiple Oppositions Model was the one that most favored the acquisitions in the phonological system and the reduction of altered distinctive features of the subjects with SD and MSD, as the subjects acquired more sounds, and established more distinctive features. We suggest the development of researches with a greater number of subjects, so that it will be possible to compare these findings.
4. Bagetti T, Mota HB, Keske-Soares M. Modelo de oposições máximas modificado: uma proposta de tratamento para o desvio fonológico. R. Soc. Bras. Fonoaudiol. 2005 Jan-Mar;10(1):36-42.

5. Ardenghi LG, Mota HB, Keske-Soares M. A terapia Metaphon em casos de desvios fonológicos. R. Soc. Bras. Fonoaudiol. 2006;11(2):106-15. 
6. Barberena LS, Keske-soares M, Mota HB. Generalização baseada nas relações implicacionais obtida pelo modelo "ABAB-Retirada e Provas Múltiplas. R. Soc. Bras. Fonoaudiol. 2008;13(2):143-53.

7. Elbert M, Gierut JA. Handbook of clinical phonology. London: Taylor \& Francis Ltda; 1986.

8. Crosbie S, Holm A, Dodd B. Intervention for children with severe speech disorder: a comparison of two approaches. Int. J. Lang. Comm. Dis. 2005 Oct-Dec;40(4):467-91.

9. Dodd B, Bradford A. A comparison of three therapy methods for children with different types of developmental phonological disorder. Int. J. Lang. Comm. Dis. 2000;35 (2):189-209

10. Mota HB, Keske-Soares M, Bagetti T, Ceron MI, Melo Filha MGC. Análise comparativa da eficiência de três diferentes modelos de terapia fonológica. Pró-Fono R. Atual. Cient. 2007 Jan-Abr;19(1):67:74.

11. Keske-Soares M, Marini C, Brancalioni AR, Ceron MI, Pagliarin KC. Eficácia da terapia para desvios fonológicos com diferentes modelos terapêuticos. Pró-Fono R. Atual. Cient. 2008;20:153-8.

12. Shriberg LD, Kwiatkowski J. Phonological disorders I: A diagnostic classification system. J. Speech Hear Dis. 1982; 47:226-41.

13. Yavas M, Hernandorena CLM, Lamprecht RR. Avaliação fonológica da criança: reeducação e terapia. Porto Alegre: Artes Médicas; 2001.
14. Bernhardt B. The application of nonlinear phonological theory to intervention with one phonologically disorders child. Clin. Ling. Phonet. 1992;6(1-2):283-316.

15. Keske-Soares T. Terapia fonoaudiológica fundamentada na hierarquia implicacional dos traços distintivos aplicada em crianças com desvios fonológicos [Tese]. Porto Alegre: Pontifícia Universidade Católica do Rio Grande do Sul. Doutorado em Letras, 2001.

16. Shriberg LD, Austin D, Lewis BA, McSweeny JL, Wilson DL. The percentage of consonants correct (PCC) metric: extensions and reliability data. J. Speech Lang. Hear. Res. 1997;40(4):708-22.

17. Gierut JA. Homonymy in phonological change. Clinic Ling. Phon. 1991;5:119-37.

18. Gierut JA. The conditions and course of clinicallyinduced phonological change. J. Speech Lang. Hear. Res. 1992 Out;35:1049-63.

19. Williams AL. On "minimal pair approaches to phonological remediation", (semin speech lang 2002; 23:57-57). Semin. Speech. Lang. 2003;24:257-8.

20. Williams AL. Multiple oppositions: case studies of variables in phonological intervention. Am. J. Speech Lang. Path. 2000b Nov;9:289-99.

21. Bagetti T. Mudanças fonológicas em sujeitos com diferentes graus de severidade do desvio fonológico tratados pelo modelo de oposições máximas modificado [Dissertação]. Santa Maria: Universidade Federal de Santa Maria. Mestrado em Distúrbios da Comunicação Humana, 2005 . 